SJ Quinney College of Law, University of Utah Utah Law Digital Commons

Wallace Stegner Center for Land, Resources, and Wallace Stegner Center for Land, Resources, and the Environment publications the Environment

$12-2015$

\title{
When Winning Means Losing: Why a State Takeover of Public Lands May Leave States Without the Minerals They Covet
}

\author{
Robert B. Keiter \\ S.J. Quinney College of Law, University of Utah, robert.keiter@law.utah.edu \\ John C. Ruple \\ S.J. Quinney College of Law, University of Utah, john.ruple@law.utah.edu
}

Follow this and additional works at: http://dc.law.utah.edu/stegner_pubs

Part of the Environmental Law Commons, and the Land Use Law Commons

\section{Recommended Citation}

Wallace Stegner Center For Land, Resources, and the Environment, Paper No. 2015-02; University of Utah College of Law Research Paper No. 143. Available at SSRN: https://ssrn.com/abstract=2701292 or http://dx.doi.org/10.2139/ssrn.2701292

This Article is brought to you for free and open access by the Wallace Stegner Center for Land, Resources, and the Environment at Utah Law Digital Commons. It has been accepted for inclusion in Wallace Stegner Center for Land, Resources, and the Environment publications by an authorized administrator of Utah Law Digital Commons. For more information, please contact valeri.craigle@law.utah.edu. 


\section{WHEN WINNING MEANS LOSING: \\ Why a State Takeover of Public Lands May Leave States Without the Minerals they Covet}

John C. Ruple *

Robert B. Keiter **

December 9, 2015

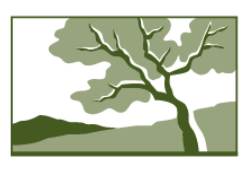

\section{Wallace Stegner Center \\ $\frac{\text { for Land, Resources and the Environment }}{\text { University OF UTAH S.J. QUINNEY COLLEGE OF LAW }}$}

Stegner Center White Paper No. 2015-02 
Introduction. This White Paper, the third in a series assessing state efforts to take over federal public lands, ${ }^{1}$ addresses state claims to the minerals underlying those lands. Our prior papers establish the disconnect between states' legal demands for title to the public domain, and takeover advocates' sincerely held belief that states would be more efficient managers - the latter simply provides no legal basis for the former. Our prior papers also demonstrate that it is a well established matter of constitutional law that the federal government retains plenary power over the public domain, including the power to retain the land in federal ownership. Furthermore, a successful takeover would raise significant fiscal and policy challenges for the states while reducing opportunities for public involvement in land management decisions.

Using Utah as an example, we argue here that even if states overcome extremely long odds to convince a court that the federal government is obligated to dispose of more public land, and that such a disposal obligation necessitates giving the public domain to the states, well established legal principles would prevent grants of most mineral lands to the states. Moreover, any mineral rights that states did obtain would be realized only after years of costly site-specific litigation - litigation above and beyond that required to test the validity of their efforts to compel disposal.

To be clear, we do not believe that the federal government is obligated to dispose of public land beyond the almost 400 million acres of land surface it already gave up in the eleven contiguous Western States. We also question whether, if a disposal obligation were found to exist, that the obligation would necessitate giving the land away or would require giving it to the states. This paper proceeds under these assumptions only for purposes of argument, and to demonstrate that even a successful takeover bid is unlikely to produce the result takeover advocates desire.

Our conclusion that states are unlikely to obtain significant mineral lands follows from two key facts: First, the federal government reserved mineral lands for itself at the time of statehood, when it expressly granted land to newly minted states. While we do not believe that additional land grants are required, it is clear that the express mineral reservations contained in other land grants should be imputed to any implied promise to dispose of additional lands recognized under any transfer theory. This reservation would prevent the targeted mineral lands from transferring to the states. Second, the scope of the federal mineral reservation is based on knowledge of the land's mineral character, which is determined when both the transfer obligation takes effect, and public land surveys are complete. However, determining the date upon which the policy favoring public domain disposal purportedly ripened (and transformed) into a legally enforceable obligation to grant lands to the states is not easily established. Furthermore, surveys of much of the West remain incomplete. Absent satisfaction of these two predicate conditions, a transfer cannot take place.

Mineral title is important because Utah's best - and perhaps only - hope of covering management costs involves mineral development. ${ }^{2}$ Indeed, during 2013, federal mineral leasing (primarily oil, natural gas, and coal) produced 93-percent of all revenue derived from the targeted public lands. ${ }^{3}$ Taking on the management of millions of acres of new land without simultaneously securing a source of funding to fulfill those obligations would be contrary to the state's best interests.

A Summary of Utah's Claims to Public Lands. On March 23, 2012, Utah's Governor signed into law the Transfer of Public Lands Act (TPLA). ${ }^{4}$ The TPLA demands that the United States extinguish title to 31.2 million acres of public lands and transfer title to those lands to the State. ${ }^{5}$ The TPLA and it's progeny proceed on the theory that the federal statutes authorizing states to join the Union and long-standing federal policy obligate the federal government to dispose of millions of acres of public land. The United 
States, according to the state, breached this promise, and takeover legislation is an attempt to force the federal government to satisfy its disposal obligation. ${ }^{6}$ The Enabling Act language relied upon by Utah is as follows:

That the people inhabiting said proposed State do agree and declare that they forever disclaim all right and title to the unappropriated public lands lying within the boundaries thereof; and to all lands lying within said limits owned or held by any Indian or Indian tribes; and that until the title thereto shall have been extinguished by the United States, the same shall be and remain subject to the disposition of the United States. ${ }^{7}$

According to the state, this statutory language obligates the federal government to "extinguish" title to unreserved public lands. By retaining title to millions of acres of National Forest and BLM lands, the federal government has failed to extinguish title to the public domain, and thus breached its obligation. The state also argues that the Enabling Act's requirement to pay Utah five-percent of the net proceeds of poststatehood public land sales demonstrate an obligation to sell off the public domain. ${ }^{8}$ The state contends that, given this breach, Utah's disclaimers of rights to additional land are inoperative. $^{9}$

The above-noted legal infirmities aside, it is important to consider precisely what states might receive were they to prevail in their claims because Utah appears intent on pursuing litigation, appropriating $\$ 2$ million for litigation planning, ${ }^{10}$ and several states are lining up to follow in Utah's footsteps. ${ }^{11}$

The Federal Government Reserved the Minerals Beneath the Public Domain. The 1889 act authorizing Montana, North Dakota, South Dakota, and Washington State to join the Union provides that "all mineral lands shall be exempt from the grants made by this act." ${ }^{12}$ Similar provisions apply with respect to Colorado, ${ }^{13}$ Idaho, ${ }^{14}$ Wyoming, ${ }^{15}$ New Mexico, ${ }^{16}$ and Arizona. ${ }^{17}$ The Utah Enabling Act, like the statehood enabling acts for California and Oregon, did not include an explicit federal mineral reservation. The U.S. Supreme Court, however, long ago dispelled any notion that Congress intended to convey mineral lands to these states.

Utah's right to mineral lands was settled almost a century ago in a dispute over title to coal land in aptly named Carbon County. The defendant, Mr. Sweet, obtained title to the disputed land from the state, which claimed title via the land grants contained in the Utah Enabling Act. The Act, according to Mr. Sweet, vested title to minerals in the state because the Act did not expressly reserve minerals, and Congress would have reserved the minerals, as it had done in other statehood enabling acts, had it not intended the minerals to pass to the state. ${ }^{18}$ The United States countered that Congress had a well-established policy of reserving minerals when it disposed of the public domain, and that the Utah Enabling Act should be read in light of this policy. Because the coal-bearing nature of the land was known prior to conveyance to the state, title to those lands could not have passed through the state to Mr. Sweet. ${ }^{19}$

The Supreme Court sided with the federal government, explaining that:

[T] he school grant to Utah must be read in the light of the mining laws, the school land indemnity law and the settled public policy respecting mineral lands, and not as though it constituted the sole evidence of the legislative will. When it is so read it does not, in our opinion, disclose a purpose to include mineral lands. Although couched in general terms adequate to embrace such lands if there were no statute or settled policy to the 
contrary, it contains no language which explicitly or clearly withdraws the designated sections, where known to be mineral in character, from the operation of the mining laws, or which certainly shows that Congress intended to depart from its long prevailing policy of disposing of mineral lands only under laws specially including them. It therefore must be taken as neither curtailing those laws nor departing from that policy. ${ }^{20}$

Indeed, Utah officials knew of the "long prevailing policy of disposing of mineral lands only under laws specially including them" well before the Sweet decision. In 1880 - sixteen years before Utah became a state - California lost a similar bid for title to mineral lands despite the absence of an explicit mineral reservation in its enabling act. In the Ivanhoe Mining case, the Supreme Court held that "[m]ineral lands are, by the settled policy of the government, excluded from all grants; therefore the grant . . . of public lands to the state of California for school purposes, was not intended to cover mineral lands." ${ }^{21}$ Critically, the Ivanhoe Mining decision held that the implied reservation applied to "all grants," not just to school grants, as adjudicated in Sweet.

Furthermore, in 1898, the General Land Office (GLO, the precursor agency to the $B L M)$ recognized an implied reservation of minerals in section eight of the Utah Enabling Act that precluded grants of mineral lands for universities. ${ }^{22}$ One year later the GLO recognized an implied reservation of minerals in section seven of the Utah Enabling Act that precluded grants of coal and mineral lands as part of the grant supporting construction of the state capitol. ${ }^{23}$ Four years later, the GLO observed that "[i]t is settled law that a grant of school lands to a State [under section six of the Utah Enabling Act] does not carry lands known to be chiefly valuable for mineral [sic] at the time when the State's right would attach, if at all." 24

Thus, both the referenced U.S. Supreme Court decisions and administrative actions establish a rule of law: that a reservation of lands mineral in character by the United States, whether express or implied, extends to all land grants to the Western States, including the State of Utah. The same reservation of lands mineral in character should be applicable as well to any remedial transfer of public lands by the United States to Utah stemming from a purported breach of the Enabling Act for failure to extinguish title to all remaining public lands. Otherwise, transferring lands known to be mineral in character to Utah under the TPLA would constitute an unsubstantiated windfall that is contrary to an established legal principle.

Despite this broad federal reservation of minerals, some mineral-rich public lands did pass to the states. During the 2013-14 fiscal year, the Utah School and Institutional Trust Lands Administration generated $\$ 103.8$ million, or three-quarters of its total revenue, from mining and oil and natural gas development on formerly federal public lands that were conveyed to Utah pursuant to the Utah Enabling Act. ${ }^{25}$ These conveyances occurred for two reasons: First, because, as the Sweet decision indicates, the federal reservation of minerals applies only where the mineral character of the land is known when the grant takes effect. ${ }^{26}$ If the mineral character of the land was not known at the time of conveyance, "subsequent discoveries will not affect the patent" and the state would be entitled to subsequently discovered minerals. ${ }^{27}$

Second, because the Jones Act, passed in $1927,{ }^{28}$ released to the states grants of numbered school sections that had been previously withheld because of mineral classification. The Jones Act, however, applies only to in-place numbered section grants supporting public schools. ${ }^{29}$ Takeover advocates do not contend that the federal government failed to meet its obligation to dispose of in-place school sections. Rather, takeover advocates contend that the federal government failed to dispose of sections other than those specifically identified in statehood enabling acts. The Jones Act, 
therefore, does not help takeover proponents, as it applies only to in-place grants in support of school grants and not to the broader purported duty to dispose addressed by the TPLA or its progeny.

Extent of the Mineral Reservation. Assuming that takeover advocates somehow prevail - an assumption we make purely for the sake of demonstrating that their victory would indeed be hollow - we turn to the scope of the federal mineral reservation.

Congress, even when it expressly reserved minerals in state enabling acts, neglected to define the term "mineral." The task of determining what substances were reserved to the federal government therefore fell to administrative agencies and the courts. ${ }^{30}$ For their part, the GLO and the courts defined minerals quite broadly, drawing little distinction between the definition of minerals under the various laws dealing with land disposition and mineral rights. ${ }^{31}$ Indeed, the Supreme Court holds that "mineral lands include not merely metalliferous lands, but all such as are chiefly valuable for their deposits of a mineral character, which are useful in the arts or valuable for purposes of manufacture."32

Once what constitutes a mineral is defined, the question becomes whether the minerals are of sufficient quantity and quality to justify classifying the lands as "mineral in character." The reservation of mineral lands, including the reservation contained in grants to states, "are not held to exclude all lands in which minerals may be found, but only those where the mineral is in sufficient quantity to add to their richness, and to justify expenditure for its extraction." ${ }^{33}$ A leading treatise on mining law in effect at the time of the Utah's admission to the Union summarizes the rules for determining the mineral character of land:

The mineral character of the land is established when it is shown to have upon or within it such a substance as - (a) Is recognized as mineral, according to its chemical composition, by the standard authorities on the subject; or (b) Is classified as a mineral product in trade or commerce; or (c) Such a substance (other than the mere surface which may be used for agricultural purposes) as possesses economic value for use in trade, manufacture, the sciences, or in the mechanical or ornamental arts. ${ }^{34}$

With respect to coal and oil bearing lands, mineral classification may be based on facts that engender a reasonable belief that the lands contain minerals, which can be established by inference from nearby geologic features. ${ }^{35}$

In sum, the existence of a potential federal reservation depends on both the nature and quantum of the mineral resource, and whether the value of those resources outweighs the value of the land for agricultural purposes. ${ }^{36}$ These are highly fact intensive and site-specific questions that the California Supreme Court summarized nicely 151 years ago when it said:

It is not easy in all cases to determine whether any given piece of land should be classed as mineral lands or otherwise. The question may depend upon many circumstances such as whether it is located in those regions generally recognized as mineral lands, or in a locality ordinarily regarded as agricultural in its character. Lands may contain the precious metals, but not in sufficient quantities to justify working them as mines, or make the locality generally valuable for mining purposes, while they are well adapted to agricultural or grazing pursuits; or they may be but poorly 
adapted to agricultural purposes, but rich in minerals; and there may be every gradation between the two extremes. There is, however, no certain, well defined, obvious boundary between the mineral lands and those that cannot be classed in that category. Perhaps the true criterion would be to consider whether upon the whole the lands appear to be better adapted to mining or other purposes. However that may be, in order to determine the question, it would, at all events, be necessary to know the condition and circumstances of the land itself, and of the immediate locality in which it is situated. ${ }^{37}$

Knowledge of coal, oil, and natural gas formations has been largely established for many years, but knowledge of other minerals may be less well defined. Where mineral resources are known to exist but development has yet to occur, the question of whether the lands are in fact mineral in character will need resolution. Hence, any state claim to potential mineral lands will necessitate extensive fact finding and litigation for each parcel claimed by the state.

When Did the Grant Take Effect? One of the most vexing questions will involve the moment in time at which knowledge of minerals, and with them the extent of the reservation, must be measured. The scope of the federal mineral reservation is defined at the moment in time when the grant of land would otherwise take effect and surveys of the land are completed.

Identifying the point in time at which the alleged promise of public land disposal ripened into an enforceable disposal obligation will be a critically important task. ${ }^{38}$ That moment in time, however, is impossible to identify. The alleged obligation takeover advocates assert was never stated explicitly in statute, but rather, was part of a broad and evolving federal land tenure policy. ${ }^{39}$ Statehood enabling acts, while purportedly embodying the promise of disposal, do not state when additional disposal was to occur, if it was to occur at all.

The most obvious explanation is that the federal government retained discretion to decide whether to dispose the land and never intended to assume further disposal obligations. ${ }^{40}$ Setting this explanation aside, we are left with what TPLA proponents characterize as a quasi-contract, but without an essential term. The absence of an essential term could prove fatal to TPLA-based claims because, as explained in the preeminent treatise on contract law, "[v]agueness of expression, indefiniteness and uncertainty as to any of the essential terms of an agreement, have often been held to prevent the creation of an enforceable contract." ${ }^{\prime 1}$

To avoid this outcome transfer proponents will likely argue that "time is neither unlimited nor discretionary ... and the promised performance must be rendered within a "reasonable time."' 42 "Reasonable time" could be construed as after fulfillment of all conditions precedent. Under this approach, the boundaries of the lands at issue and the rights reserved to the federal government can be determined only after the land is surveyed. But roughly thirty percent or more of Nevada and Utah has yet to be surveyed (see next section), meaning that unsurveyed portions of the public domain cannot be transferred out of federal ownership. Even where surveys are complete, the federal government should be afforded a reasonable period following survey completion to determine how best to dispose of the land in question (e.g., public auctions, over the counter sales, grants to states, or via some other method). There is little if any information with which to bound a "reasonable" post-survey time period, but given that Utah is asserting a claim to 31.2 million acres of land, a reasonable time period would presumably extend for several years. 
Another option would be setting the time of performance for disposal of the public domain to coincide with enactment of the Federal Land Policy and Management Act of 1976 (FLPMA). ${ }^{43}$ FLPMA announced as national policy that "the public lands be retained in Federal ownership, unless . . . it is determined that disposal of a particular parcel will serve the national interest." 44 FLPMA, because of its codification of retention policies, is often identified as ending the era of public land disposal and could conceivably be regarded as the date upon which the federal government refused to honor its disposal obligation. The refusal could therefore mark the date of the breach even if the time of performance remains uncertain. Setting the date of the breach to coincide with FLPMA's enactment would reserve to the federal government all lands that were known to be mineral in character as of 1976 (or later where public land surveys remained incomplete). By then, though, most valuable minerals were likely identified with sufficient certainty to be included in a federal mineral reservation, thereby precluding their conveyance to the states.

Or, the alleged obligation to dispose of the public domain may arguably have occurred only after Utah demanded performance and the federal government refused. Because the TPLA gave the United States until December 31, 2014, to dispose of the public lands within Utah, ${ }^{45}$ the resources subject to disposal under this interpretation would be defined no earlier than that date. Under this approach, even more mineral lands would likely have been identified, leaving the state with little in terms of new mineral wealth. With few minerals lands eligible for conveyance to the state, Utah would have limited access to the revenue needed to support management of the acquired lands. If performance is tied to state demand statutes, states following Utah's lead would fare even worse, as their demands would be based on even later effective dates.

Finally, there is the problem of formulating a judicial remedy. The remedy issues are extensive and complex: Courts would need to resolve how much additional public land must be disposed of, who would decide what lands would be disposed of, what standards they would apply in making that determination, to whom the land would or could be conveyed to (e.g. states, individuals, or corporations), the means of disposal (e.g. grants or sales, in fee or while reserving minerals), the deadline for disposal, and the list goes on. The cost of this litigation would be borne by the state before transfer could occur and without any guarantee of a favorable outcome.

Survey Completion. One additional fatal flaw stands in the way of takeover advocates' dreams of wholesale public land transfers - the absence of the land surveys needed in advance of conveyance. The public land survey system divides the landscape into townships, each of which contains thirty-six sections. Each section is normally one square-mile in size (640 acres). ${ }^{46}$ Utah's Enabling Act grants included four sections in every township within the state. ${ }^{47}$ The enabling acts for other Western States contain similar provisions, though most Western States received less land than Utah. ${ }^{48}$ Where these "in place" grants were subject to prior sales, grants, or reservations, states had the right to select "in-lieu" lands. States were also granted so-called "quantity grants," which included a specified number of acres that the state could select from the surveyed public domain. ${ }^{49}$

Conveyance of these lands to the states depended on completion of public land surveys because the boundary of lands to be conveyed could not be marked on the ground or defined with adequate legal precision in conveyance documents until township and section lines were surveyed and the appropriate parcel boundaries defined. ${ }^{50}$ Where surveys were completed prior to states joining the Union, the effective date of the grants coincides with statehood. ${ }^{51}$ As the Supreme Court explained with respect the Wyoming's land grants: 
$[T]$ itle to unsurveyed sections of the public lands which have been designated as school lands does not pass to the State upon its admission into the Union, but remains in the Federal Government until the land is surveyed. Prior to survey, those sections are a part of the public lands of the United States and may be disposed of by the Government in any manner and for any purpose consistent with applicable federal statutes. . . . The interest of the State vests at the date of its admission into the Union only as to those sections which are surveyed at that time and which previously have not been disposed of by the Federal Government. ${ }^{52}$

The Court went on to express its reluctance at upsetting this well-established rule, noting specifically that many prior decisions rest on its application, and a departure could produce unequal outcomes among the several states. ${ }^{53}$

The Wyoming decision, however, addressed in place school section grants, and Utah is not demanding title to in place school sections (which it has already received). Rather, Utah is seeking title to some ill-defined other suite of public lands. Whether a court would apply the Wyoming reasoning in the context of TPLA-based claims is not clear. The policy underpinnings appear to be the same, particularly with respect to the need for pre-disposal surveys, suggesting a similar holding. But given the import of the question, it should be assumed that this issue too would be hotly contested.

Despite ongoing efforts to survey the West, ${ }^{54}$ millions of acres of the public domain have never been surveyed. In Nevada, for example, approximately thirty-percent of the state remains unsurveyed. ${ }^{55}$ Maps depicting the condition of surveys in Utah were completed during 2008-09, and indicate that roughly one-third of the state has never been surveyed. ${ }^{56}$ Notably, school trust land sections have been surveyed, but surrounding federal lands often have not. Figure 1 provides an example showing the condition of surveys for the BLM's Monticello, Utah Field Office. In general, the southeastern portion of Utah has more unsurveyed land than other portions of the state, perhaps because of the region's rugged topography. It appears that the lands most likely to contain accessible minerals were surveyed first and that the remaining unsurveyed lands have either little known mineral value, or that the unsurveyed lands would be prohibitively expensive to develop because of rugged topography or limited access to markets. 
Figure 1.

Condition of Survey, BLM's Monticello, Utah Field Office (2009)

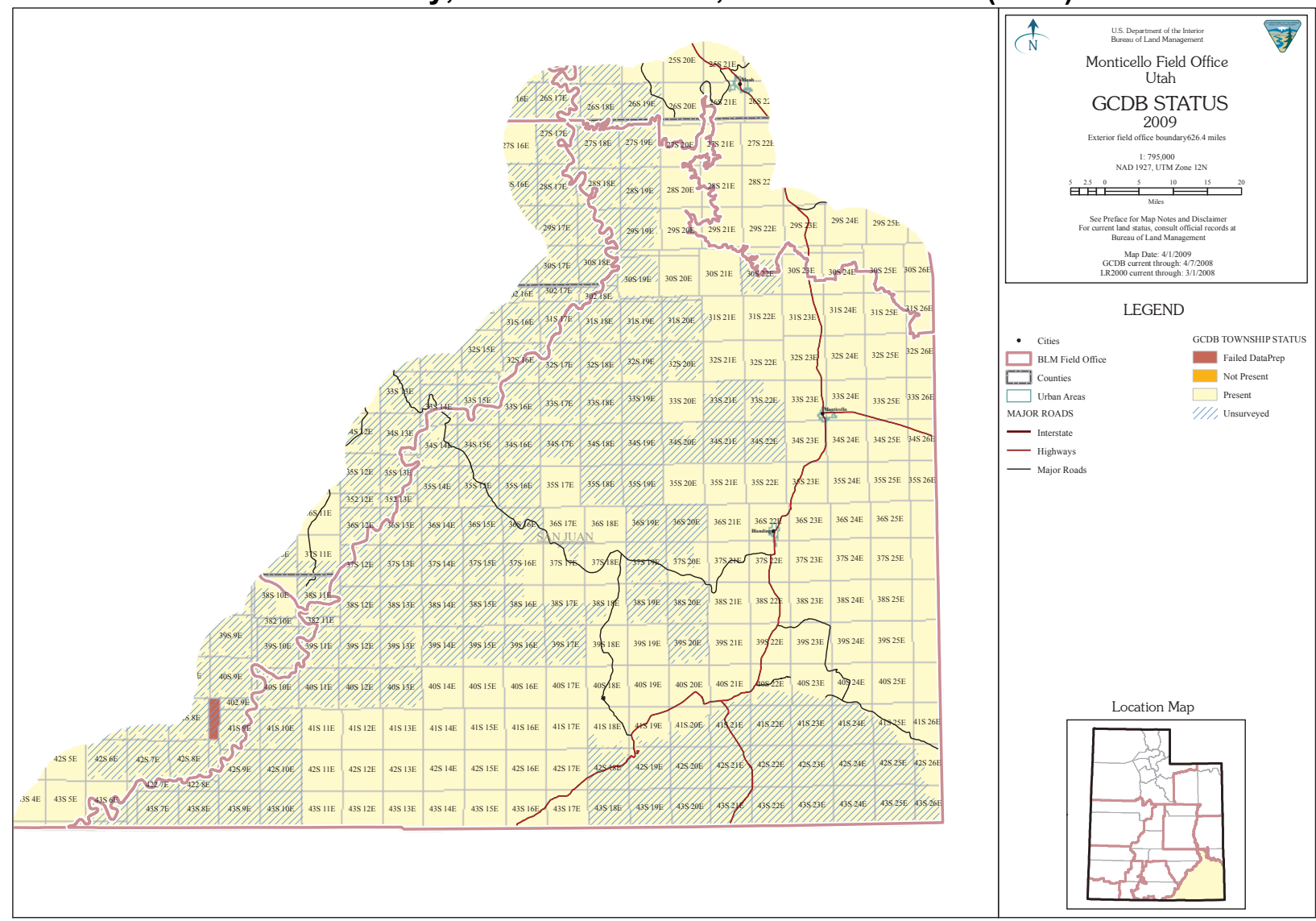

Conclusion. Improving the condition and management of our nation's public lands is a laudable goal, even if we may disagree about how best to achieve that end. That said, there is a fundamental disconnect between assertions that states would be better managers, and demands that the federal government surrender title to the public domain. Moreover, states have extremely weak legal claims to compel additional public land disposal, disposal would not necessarily require grants to the states, and even if the states somehow were to prevail in takeover litigation, "success" would inevitably prompt decades of additional litigation.

The first round of post-TPLA litigation would need to address how much additional public land must be disposed of, who would decide what lands would be disposed of, what standards they would apply in making that determination, to whom the land would or could be conveyed to, whether lands should be sold to the highest bidder or granted to deserving parties, whether mineral rights would be reserved to the federal government, and the deadline for effectuating disposal.

Once these preliminary questions were resolved, courts would need to address at least five questions involving mineral rights for each parcel of land at issue. The first question would involve the point in time at which the federal government was obligated to dispose of the remainder of the public domain. The second question would involve the existence and adequacy of cadastral surveys of the public lands. The third question would involve what was known about minerals on or beneath each parcel of land subject to a disposal obligation at the point in time when surveys were completed and the promise of disposal ripened into an enforceable obligation. The fourth question would be 
whether, based on this information, the land should be classified as mineral in character, thereby defeating the state's claims to land title. The final question would involve whether lands were otherwise reserved by the federal government or conveyed out of public ownership (in whole or with respect to individual mineral interests) before the disposal obligation became legally enforceable.

All five of these questions involve matters specific to each individual parcel of land. Given the fact-intensive nature of these claims and Utah's demand for title to 31.2 million acres of land, these claims would likely take decades to resolve. Such litigation would involve significant costs and greatly delay the states' efforts to secure title. These costs, moreover, would accrue to the states before they could obtain any new revenue from the targeted lands, and without any guarantee of a favorable judicial outcome.

Given the likely extent of the federal mineral reservation, it appears that even if Utah or her sister states were to somehow prevail in TPLA litigation, the states are unlikely to secure title to significant new mineral resources. Securing public lands with limited revenue generating potential would burden states with all of the costs of management without providing significant additional revenue to cover those expenses. It is ironic that in 1932, Congress considered conveying ownership of the vacant, unappropriated, and unreserved non-mineral public lands to the states. ${ }^{57}$ The states opposed the proposal, fearing that without control of the minerals they could not afford the expense of management. ${ }^{58}$ Yet today, TPLA advocates are rushing towards the same financial cliff, either unaware of the likely consequences or unwilling to acknowledge them.

* John C. Ruple is an Associate Professor of Law (Research), and Wallace Stegner Center Fellow at the University of Utah's S.J. Quinney College of Law.

** Robert B. Keiter is the Wallace Stegner Professor of Law, University Distinguished Professor, and Director of the Wallace Stegner Center for Land, Resources \& the Environment at the University of Utah's S.J. Quinney College of Law.

${ }^{1}$ Robert B. Keiter \& John C. Ruple, A Legal Analysis of the Transfer of Public Lands Movement, STEgneR CENTER WHITE PAPER 2014-02 (2014) http://papers.ssrn.com/sol3/papers.cfm?abstract id=2516004, and Robert B. Keiter \& John C. Ruple, The Transfer of Public Lands Movement: Taking the 'Public' Out of Public Lands, Stegner CenTER WhITE PAPER 2015-01 (2015) http://papers.ssrn.com/sol3/papers.cfm?abstract id=2555922.

2 Taking the 'Public' Out of Public Lands, supra note 1.

${ }^{3}$ A recent state-commissioned economic study concluded that Utah cannot foreseeably cover management costs under any scenario that does not involve a significant increase in commodity production coupled with an increase in commodity prices. UNIVERSITY OF UTAH, UTAH STATE UNIVERSITY \& WEBER STATE UNIVERSITY, AN ANALYSIS OF A TRANSFER OF FEDERAL LANDS TO THE STATE OF UTAH XXVI (2014), http://publiclands.utah.gov/wpcontent/uploads/2014/11/1.\%20Land\%20Transfer\%20Analysis\%20Final\%20Report.pdf. 
${ }^{4}$ H.B. 148, 2012 Gen. Sess. (Utah), codified at UTAH CODE ANN. §§ 63L-6-101 through 104 (2014).

${ }^{5}$ UTAH CODE ANN. § 63L-6-103(1) (2014).

${ }^{6}$ For a summary of Utah's arguments, see UTAH CONSTITUTIONAL DEFENSE COUNCIL, TOWARD A BALANCEd PUBliC LANDS POLICY - A CASE STATEMENT FOR THE H.B. 148: UTAH'S TRANSFER OF PUBLIC LANDS ACT (2012) (hereinafter TPLA CASE STATEMENT) http://publiclands.utah.gov/wp-content/uploads/2013/08/Toward-a-Balanced-PublicLands-Policy-A-Case-Statement-for-H.B.-148.pdf.

${ }^{7}$ Enabling Act of Utah, 28 Stat. 107, 108 (1894) (emphasis added).

${ }^{8}$ Id. at 110; TPLA CASE STATEMENT, supra note 6 , at 4.

${ }^{9}$ See TPLA CASE STATEMENT, supra note 6 , at 3.

10 Off. of the Legis. Fiscal Analyst, Budget of the State of UtAH and Related APPROPRIATIONS 2014-2015, 2014-15 Gen. Sess., at 196 (2014) http://le.utah.gov/interim/2014/pdf/00003542.pdf; STATE OF UTAH, SOLICITATION RFP2015-01, LEGAL/RELATIONS SERVICES - OBTAINING PUBLIC LANDS FROM THE FEDERAL GoVERNMENT (Feb. 23, 2015) (on file with authors). See also, Brian Maffly, Utah Lawmakers Want \$500K to Study How Public Land Transfer May Benefit Schools, SALT LAKE TRIBUNE, March 10, 2015, http://www.sltrib.com/news/2275111-155/utahlawmakers-want-500k-to-study.

${ }^{11}$ National Conference of State Legislatures, State Legislation Addressing Transfer of Federal Public Lands to States (2014). See also, Kindra McQuillan, State Bills to Study Federal-to-State Land Transfers: A Rundown of the Legislation in Each State and a Look into the Motives Behind Them, HIGH COUNTRY NEWS (April 30, 2015).

1225 Stat 676, 681 (1889).

1318 Stat. 474, 476 (1875), as amended Apr. 2, 1884, c. 20, 23 Stat. 10.

${ }^{14} 26$ Stat. 215, 217 (1890).

${ }^{15} 26$ Stat. 222, 224 (1890).

${ }^{16} 36$ Stat. 557, 561 (1910).

17 Id. at 572.

${ }^{18}$ United States v. Sweet, 245 U.S. 563 (1918).

${ }^{19}$ For a comprehensive history of the widespread fraud involved in efforts to obtain title to coal bearing lands in Utah, including Mr. Sweet's claims, see NANCY J. TANIGUCHI, NeCessary Fraud, Progressive Reform ANd UtaH CoAl (1996).

${ }^{20} 245$ U.S. at 572-73 (internal citations omitted), Cited with support in Andrus v. Utah, 446 U.S. 500, 508-09 (1980).

${ }^{21}$ Ivanhoe Mining Co. v. Keystone Consol. Mining Co., 102 U.S. 167, 174-75 (1880).

22 Ricther v. Utah, 27 Pub. Lands Dec. 95 (1898).

${ }^{23}$ State of Utah, 29 Pub. Lands Dec. 69 (1899). 
${ }^{24}$ State of Utah, 32 Pub. Lands Dec. 117 (1903). See also, Mahoganey No. 2 Lode Claim, 33 Pub. Land Dec. 37 (1904).

${ }^{25}$ StATE OF UTAH SCHOOL AND INSTITUTIONAL TRUST LANDS ADMINISTRATION, FISCAL YEAR 2014 ANNUAL REPORT 4 (2015).

${ }^{26} 245$ U.S. at 572.

${ }^{27}$ Diamond Coal \& Coke Co. v. U.S., 233 U.S. 236, 240 (1914). See also, CuRTIS H. LINDLEY, A TREATISE ON THE AMERICAN LAW RELATING to Mines AND MineRAL LANDS $\S$ 141 (1897) ("It is, of course, conceded that after a right has once vested to a tract of land which, at the time it became segregated from the body of the public domain and passed to states or individuals, was non-mineral, according to the state of the law and the facts then existing, no subsequent change in commercial conditions nor advancement in the industrial arts can effect those rights.").

${ }^{28}$ See Pub. L. No. 69-570, 44 Stat. 1026 (1927) (codified as amended in 43 U.S.C. $\S \S$ 870-71 (2012)).

${ }^{29} 43$ U.S.C. $\S 870$ (2012).

${ }^{30}$ LINDLEY, supra note 28 at $\S 86$ (1897) ("No legislative interpretation or definition of the term 'mineral lands,' which were so reserved and excepted, was ever attempted. This was left for judicial or departmental construction.").

${ }^{31}$ See id., ('the term 'mineral lands,' and its equivalent terms, wherever used in the acts or grants of congress, either as words of reservation or in the mining laws authorizing their appropriation, has the same limit and breadth of signification. What had been reserved by one series of legislative enactments, and in the different legislative grants, is identically that the appropriation of which is encouraged and sanctioned by another series of laws.").

32 Northern Pacific Railway Co. v. Soderberg, 188 U.S. 526, 536-37 (1903).

${ }^{33}$ Davis v. Wiebbold, 139 U.S. 507, 519 (1891); see also, Deffeback v. Hawke, 115 U.S. 392, 404 (1885) ("We say 'land known at the time to be valuable for its minerals,' as there are vast tracts of public land in which minerals of different kinds are found, but not in such quantity as to justify expenditures in the effort to extract them. It is not to such lands that the term 'mineral,' in the sense of the [1866 Mining Act], is applicable.").

${ }^{34}$ LINDLEY, supra note 28 at $\S 98$.

${ }^{35}$ Diamond Coal \& Coke, 233 U.S. at 249 (inferring knowledge of coal from proximate geology and development activity). See also, 1 ROCKY MOUNTAIN MINERAL LAW FOUNDATION, AMERICAN LAW OF MINING, 2D ED. §[12.02[4]] (LEXISNEXIS MATTHEW BENDER 2015).

${ }^{36} 233$ U.S. at $239-40$.

${ }^{37}$ Ah Yew v. Choate, 24 Cal. 562, 567-68 (1864).

${ }^{38}$ AMERICAN LAW OF MINING, supra note 36 at $\S 61.02$ ("It therefore was, and still is in many instances, vital to determine the effective date of state grants.").

39 This policy was not absolute, with the federal government also withdrawing and reserving lands and minerals from disposal since the birth of the republic. A Legal Analysis of the Transfer of Public Lands Movement, supra note 1 at 2-3. 
${ }^{40}$ This argument is particularly compelling given that statehood enabling acts commonly required newly admitted states to disclaim their right to additional public lands above and beyond those lands specifically identified in the enabling acts. See e.g., 13 Stat 30, 31 (1864) (Nevada), 25 Stat. 676, 681 (1889) (North Dakota, South Dakota, Montana, and Washington), 26 Stat. 215, 217 (1890) (Idaho), 26 Stat. 222,224 (1890) (Wyoming), and 28 Stat. 107, 108 (1894) (Utah).

41 1-4 CORBIN ON CONTRACTS $\S 4.1$.

42 Id. at $\S 4.2$.

4343 U.S.C. $\$ \S 1701-84$ (2012).

4443 U.S.C. $\S 1701(a)(1)(2012)$.

${ }^{45}$ UTAH CODE ANN. § 63L-6-103(1) (2014).

${ }^{46}$ See 43 U.S.C. $§ 751$ (2012).

4728 Stat. 107, 109 (1894).

48 Though beyond the scope of this paper, it should be noted that if the federal government's alleged breach of its duty to dispose occurred in 1976, the State of Utah and its peers would have been aware of this breach for almost forty years. Knowledge of the alleged breach combined with "substantial improvements or substantial investments [by a federal lessee or right of way grantee] or on which the United States has conducted substantial activities pursuant to a management plan such as range improvement, timber harvest, tree planting, mineral activities, farming, wildlife habitat improvement, or other similar activities" would toll the statute of limitations which, under the federal Quiet Title Act, 28 U.S.C. § 2409a(i) (2012), would bar claims made more than twelve years "after the date the State received notice of the Federal claims to the lands." The state would be no better off characterizing the action as a contractual dispute rather than a Quiet Title Act claim because "every civil action commenced against the United States shall be barred unless the complaint is filed within six years after the right of action first accrues." 28 U.S.C. $§ 2501$ (a) (2012). If the state overcomes the statute of limitations hurdle it must still contend with a laches defense. (Laches "is defined as neglect to assert a right or claim which, taken together with lapse of time and other circumstances causing prejudice to the adverse party, operates as a bar in court of equity." BLACK'S LAW DICTIONARY (Abridged 6th ed. 1991).

${ }^{49}$ See e.g., 28 Stat, 107, 109-10 (1894) (Utah Enabling Act). Settlement, however, predated surveys. Thus, where land that would otherwise have passed to the state had already been conveyed out of federal ownership or reserved for federal purposes, states were granted the right to select other lands "in lieu" of the lands they would have received. See 28 Stat. 107, 109 (1894) (Utah Enabling Act). See also, Andrus v. Utah, 446 U.S. 500 (1980) (limiting Utah's in lieu selection to lands that did not have widely disparate value).

50 George Cameron Coggins and Robert L. Glicksman, 2 Pub. Nat. Resources L. $\S$ 13:51 (2nd ed. 2010) ("Precise boundaries are necessary for secure land titles.").

${ }^{51}$ United States v. Wyoming, 331 U.S. 440, 443-44 (1947).

52 Id., see also Heydenfeldt v. Daney Gold \& Silver Mining Co., 93 U.S. 634 (1877) (interpreting Nevada Enabling Act), and Andrus v. Utah, 446 U.S. 500, 506-07 (1980) 
(internal citations omitted) ("Whether the Enabling Act contained words of present or future grant, title to the numbered sections did not vest in the State [of Utah] until completion of an official survey. Prior to survey, the Federal Government remained free to dispose of the designated lands 'in any manner and for any purpose consistent with applicable federal statutes."”).

53331 U.S. at 454 (internal citations omitted).

${ }^{54}$ During FY 2014, the Department of the Interior, within Utah, completed original surveys of 21,385 acres, and resurveys of 112,263 acres. Alaska and Arizona were the only states where more original surveys were completed, and no state resurveyed more acres. BuREAU OF LAND MGMt., U.S. DEP'T OF THE INTERIOR, PUBLIC LAND STATISTICS 2014, 24 (2015).

55 "In Nevada, the GLO/Cadastral surveys were initiated in 1861. Current survey conditions in Nevada have approximately $40 \%$ of Nevada townships surveyed prior to 1910 and monumented with stone or wooden posts at the corner points. Another $30 \%$ are [sic] surveyed after 1910 utilizing metal post and brass cap monuments at the corner points. The remaining $30 \%$ is unsurveyed land." Bureau of Land Mgmt., Cadastral Survey, http://www.blm.gov/nv/st/en/prog/more programs/geographic sciences/cadastral.html.

${ }^{56}$ Estimates are based on fifteen Geographic Coordinate Database Section Status (GCDB) maps prepared by the Bureau of Land Mgmt., U.S. Dep't of the Interior (on file with authors).

${ }^{57}$ See S. 17, 72nd Cong., 1st Sess. (1932), S. 2272, 72nd Cong., 2d Sess. (1932), and S. 4060, 72nd Cong., 2d Sess. (1932).

${ }^{58}$ Don B. Colton, Control of the Public Domain: A National or State Function?, N.Y. TIMES, Apr. 10, 1932, pp. 1, 11. See also, UtAH CONSTITUTIONAL DEFENSE CounCIL, REPORT ON UTAH'S TRANSFER OF PUBLIC LANDS ACT H.B.148, 17-19 (2012) http://publiclands.utah.gov/wp-content/uploads/2013/08/Report-on-Utahs-Transfer-ofPublic-Lands-Act-H.B.-148.pdf (quoting George Dern, then Governor of Utah), 